University of Nebraska - Lincoln

DigitalCommons@University of Nebraska - Lincoln

Agronomy \& Horticulture -- Faculty Publications

Agronomy and Horticulture Department

4-19-2007

\title{
Increased abundance of arbuscular mycorrhizal fungi in soil coincides with the reproductive stages of maize
}

\author{
M. Susana Grigera \\ University of Nebraska-Lincoln \\ Rhae A. Drijber \\ University of Nebraska-Lincoln, rdrijber1@unl.edu \\ Brian J. Wienhold \\ University of Nebraska-Lincoln, Brian.Wienhold@ars.usda.gov
}

Follow this and additional works at: https://digitalcommons.unl.edu/agronomyfacpub

Part of the Plant Sciences Commons

Grigera, M. Susana; Drijber, Rhae A.; and Wienhold, Brian J., "Increased abundance of arbuscular mycorrhizal fungi in soil coincides with the reproductive stages of maize" (2007). Agronomy \& Horticulture -- Faculty Publications. 33.

https://digitalcommons.unl.edu/agronomyfacpub/33

This Article is brought to you for free and open access by the Agronomy and Horticulture Department at DigitalCommons@University of Nebraska - Lincoln. It has been accepted for inclusion in Agronomy \& Horticulture -Faculty Publications by an authorized administrator of DigitalCommons@University of Nebraska - Lincoln. 


\title{
Increased abundance of arbuscular mycorrhizal fungi in soil coincides with the reproductive stages of maize
}

\author{
M. Susana Grigera ${ }^{a}$, Rhae A. Drijber ${ }^{a, *}$, Brian J. Wienhold ${ }^{\mathrm{b}}$ \\ ${ }^{a}$ Department of Agronomy and Horticulture, 279 Plant Science, University of Nebraska-Lincoln, Lincoln, NE 68583-0915, USA \\ ${ }^{\mathrm{b}}$ ARS-USDA, 120 Keim Hall, Lincoln, NE 68583-0934, USA
}

Received 29 June 2006; received in revised form 14 November 2006; accepted 20 November 2006

Available online 18 January 2007

\begin{abstract}
Arbuscular mycorrhizal (AM) fungi are recognized for their positive effects on plant growth, playing an important role in plant $\mathrm{P}$ nutrition. We used C16:1 cis11 and C18:1 cis11 fatty acid methyl ester (FAME) biomarkers to monitor the dynamics of AM fungi during the reproductive stages of maize (Zea mays L.) grown at high yield in Nebraska, USA. Two fields with four different levels of $\mathrm{P}$ availability were sampled throughout the reproductive stages. Chambers, made of PVC enclosed mesh fabric to allow passage of roots and hyphae $(+\mathrm{R})$ or hyphae alone $(-\mathrm{R})$ and amended with either $\mathrm{KH}_{2} \mathrm{PO}_{4}(+\mathrm{P})$ or distilled water $(-\mathrm{P})$, were installed in the field at tasselling and removed after three, six and nine weeks. Our objectives were (i) to provide evidence for $\mathrm{C}$ allocation to AM fungi during the reproductive stages of high productivity maize and (ii) to link AM fungal growth dynamics with changes in soil P availability. We observed that initial AM FAME concentration was lower at sites with a high availability of P. During the reproductive growth of maize, AM biomarkers increased inside the chambers and were consistent with the biomarker increase observed in adjacent field soil. This confirms that there is $\mathrm{C}$ allocation from the plant to the symbiont during the reproductive stages of maize. We also observed a reduction in available $\mathrm{P}$ in $+\mathrm{R}$ and $-\mathrm{R}$ chambers. This observation implies that hyphae were as efficient as roots and hyphae in reducing the $\mathrm{P}$ concentration in chambers. These results demonstrate that AM fungi are active during the reproductive growth stages of maize and may benefit high productivity maize crops by facilitating $\mathrm{P}$ uptake.
\end{abstract}

(C) 2007 Elsevier Ltd. All rights reserved.

Keywords: AM fungi; FAMEs; Bray P; Maize (Zea mays L.)

\section{Introduction}

Arbuscular mycorrhizal (AM) fungi form symbiotic relationships with up to $80 \%$ of land plants and are also recognized for their positive effects on plant growth and soil quality (Smith and Read, 1997). The extramatrical growth of the mycelium is a key factor in nutrient acquisition by the mycorrhizal symbiont (Olsson et al., 1997). Phosphorous is an essential plant nutrient and, following $\mathrm{N}$, is the second most common fertilizer nutrient applied in crop production. Although $\mathrm{P}$ supply during early development has an effect on crop yield potential (Grant et al., 2001), there may also be a requirement for additional $\mathrm{P}$ later in crop growth. In maize (Zea mays L.),

\footnotetext{
${ }^{*}$ Corresponding author. Tel.: + 1402472 0770; fax: + 14024727904

E-mail address: rdrijber1@unl.edu (R.A. Drijber).
}

$\mathrm{P}$ accumulates steadily until maturity, with a high proportion (approximately 60\%) being absorbed during the reproductive period (Karlen et al., 1988). Phosphate transport across the root is usually faster than diffusive transport in soil. This lowers the concentration of phosphate in the soil solution surrounding the root forming a P depletion zone (Barber, 1977). This gap may be bridged by AM fungi.

Several studies document reduced mycorrhizal colonization of plants with increased $\mathrm{P}$ availability (Olsson et al., 1997); however, plant P concentration (Koide and Li, 1990) and $\mathrm{N}$ supply (Liu et al., 2000) may be more important. Recently, it was shown that AM fungi contribute significantly to $\mathrm{P}$ uptake by wheat, even in the presence of added $\mathrm{P}$ (Li et al., 2006). In maize, Liu et al. (2000) found a positive correlation between the shoot/root ratio and the degree of AM colonization of roots. The amount of dry matter in 
maize roots remains almost constant shortly after reproductive growth begins at R1 (Ritchie et al., 1997). The below ground dry matter/above ground dry matter ratio is maximum at V10 (61\%) and decreases with time, being $25-34 \% 7$ days before R1, $17-20 \%$ at R1, and $10-13 \%$ at R5 (Plenet, 1995). Thus, maize grown at high yield may be more dependent on AM fungi for nutrient acquisition to support increased above ground biomass.

The uniqueness and utility of fatty acid methyl ester (FAME) biomarkers for AM fungi has been demonstrated by several authors. Larsen et al. (1998) used fatty acid signatures to study mycelial interactions between AM fungi and saprotrophic fungi in root-free soil. The dominant fatty acid for saprotrophic fungi was $\mathrm{C} 18: 2$ cis 9,12 while it was negligible in mycelium of Glomus intraradices. The fatty acids C16:1cis 11, C20:4, and C20:5 were found in this AM fungus, but not in the saprotrophic ones. FAME analysis performed on the spores of four AM fungi (G. coronatum, G. mosseae, Gigaspora margarita and Scutellospora calospora) showed C16:1cis11 to be the dominant fatty acid present (Madan et al., 2002). Furthermore, Olsson and Johansen (2000) found that the amount of phospholipid fatty acid (PLFA) C16:1 cis11 per unit biomass of two AM species (G. intraradices and G. clarideum) remained rather constant as the mycelium aged, and its distribution between spores and hyphae was highly consistent making it a suitable biomass indicator. Gryndler et al. (2006) reported significant positive correlations between whole cell extracted C16:1 cis 11 and AM hyphal lengths in field soils. van Aarle and Olsson (2003) observed that NLFA and PLFA were similarly correlated with AM \% root colonization of Plantago lanceolata L in monoxenic cultures. In soils, NLFA C16:1 cis 11 may be a more sensitive indicator of AM fungal biomass due to high background concentrations of PLFA C16:1cis11 (Olsson, 1999).

The relative amount of C16:1 cis 11 in roots may provide an index of the amount of $\mathrm{C}$ allocated for fungal growth and lipid storage in the root during the colonization process (Graham et al., 1995). We used this approach to understand the dynamics of mycorrhizal fungi during the reproductive stages of high productivity maize. Management systems that enhance natural mechanisms for $\mathrm{P}$ acquisition will help to optimize the use of $\mathrm{P}$ fertilizer resources. We hypothesize that AM fungi are essential to meet the demand for $\mathrm{P}$ during the reproductive stages of maize managed for high yield. Our objectives were (i) to provide evidence for $\mathrm{C}$ allocation to $\mathrm{AM}$ fungi during the reproductive stages of high productivity maize and (ii) to link AM fungal growth dynamics with changes in soil $\mathrm{P}$ availability.

\section{Materials and Methods}

\subsection{Study area}

The field study was conducted during 2004 near Shelton NE $\left(40^{\circ} 45^{\prime} 01^{\prime \prime} \mathrm{N}, 98^{\circ} 46^{\prime} 01^{\prime \prime} \mathrm{W}\right)$ and Lincoln, NE $\left(40^{\circ} 49^{\prime} 12^{\prime \prime} \mathrm{N}, 95^{\circ} 39^{\prime} \mathrm{W}\right)$. Soils at Shelton are Hord silt loam (Fine-silty, mixed mesic Pachic Argiustoll, 0-1\% slope) and Blendon loam (Coarse-loamy, mixed mesic Pachic Haplustoll, 0-1\% slope). Continuous maize has been cropped since 1990 under conventional disk tillage with furrow irrigation, and since 1996 under reduced tillage (disk and field cultivator) with sprinkler irrigation. Prior to planting, $168 \mathrm{~kg} \mathrm{Nha}^{-1}$ as urea ammonium nitrate solution was incorporated with a field cultivator. Maize (Pioneer 33B51) was planted on 2 May, 2004 with $19.5 \mathrm{~kg} \mathrm{Pha}^{-1}$, and $13.1 \mathrm{~kg} \mathrm{Nha}^{-1}$ as diammonium phosphate applied adjacent to the seed. Stand density was 71,600 plants ha $^{-1}$ and field average yield was $12.2 \mathrm{Mgha}^{-1}$ at $155 \mathrm{~g} \mathrm{~kg}^{-1}$ moisture content.

In May 2003, apparent electrical conductivity (ECa) was measured with an EM 38 dual dipole conductance meter (Geonics Ltd., Mississauga, Ont., Canada) pulled behind an all terrain vehicle (Grigera et al., 2006). The data collected were processed using ERDAS Imagine (ERDAS Inc., Atlanta, GA) to create four ECa classes based on ranges of ECa measurements using unsupervised classification (ERDAS, 1997) (Johnson et al., 2001). Six sites in ECa classes II and IV were randomly selected for soil sampling and to study mycorrhizal dynamics.

Soil at Lincoln is a deep Kennebec silty clay loam (Finesilty, mixed, superactive, mesic Cumulic Hapludolls $0-1 \%$ slope). Continuous maize has been cropped since 1999 under conventional tillage with sprinkler irrigation. The field was plowed in the fall using a Salford conservation tillage plow (Salford Farm Machinery Limited, Salford, ON, Canada) (about $25-30 \mathrm{~cm}$ deep), and field cultivated before planting. The experiment was arranged in a randomized complete block design with four replicates. Two levels of fertilizer-nutrient management were applied: recommended (M1) and intensive (M2). For M1, a total of $200 \mathrm{~kg} \mathrm{Nha}^{-1}$ as ammonium nitrate was applied: $100 \mathrm{~kg} \mathrm{~N} \mathrm{ha}^{-1}$ incorporated with a field cultivator prior to planting, and $100 \mathrm{~kg} \mathrm{Nha}^{-1}$ at V6. For M2, a total of $280 \mathrm{~kg} \mathrm{ha}^{-1}$ of $\mathrm{N}$ was applied as follows: $50 \mathrm{~kg} \mathrm{Nha}^{-1}$ in October 2003 as UAN on crop residue (before plowing), $80 \mathrm{~kg} \mathrm{ha}^{-1}$ as ammonium nitrate prior to planting, 60,50 and $40 \mathrm{~kg} \mathrm{Nha}^{-1}$ as ammonium nitrate at V6, V10 and V14, respectively. In addition, $45 \mathrm{~kg} \mathrm{ha}^{-1} \mathrm{P}$ as single super phosphate and $85 \mathrm{kgha}^{-1} \mathrm{~K}$ as $\mathrm{KCl}$ were broadcasted before planting and incorporated. Maize (Pioneer 31N28) was planted on 12 May, 2004. Stand density was 74000 plants ha $^{-1}$, and field average yield for M1 was $15.5 \mathrm{Mg} \mathrm{ha}^{-1}$ and for $\mathrm{M} 2$ was $15.6 \mathrm{Mg} \mathrm{ha}^{-1}$ at $155 \mathrm{~g} \mathrm{~kg}^{-1}$ moisture content.

\subsection{Preparation and installation of soil chambers}

Bulk soil to fill the chambers was collected from the 0 - to 15-cm depth on 22 June from two sites each in ECa II and ECa IV at Shelton and M1 and M2 at Lincoln. Field moist soil was passed through a $6 \mathrm{~mm}$ mesh sieve to remove plant residues and stored at $4{ }^{\circ} \mathrm{C}$ until chambers were prepared. 
These soil samples were analyzed for Bray P (Bray and Kurtz, 1945), total, and organic P (Olsen and Sommers, 1982). The chambers were made of PVC with a wall thickness of $0.6 \mathrm{~cm}$, a diameter of $10 \mathrm{~cm}$, and a height of $4.5 \mathrm{~cm}$. The sides of the rings were enclosed with $1 \mathrm{~mm}$ mesh fabric to allow $(+\mathrm{R})$ or $0.04 \mathrm{~mm}$ mesh fabric to exclude (-R) maize roots (Sefar America Inc., Depew, NY). Both mesh sizes allowed hyphal penetration. Rings were filled with approximately $425 \mathrm{~g}$ of bulk soil from either ECa II, ECa IV, M1 and M2, amended with either $20 \mathrm{ml}$ of $0.014 \mathrm{M} \mathrm{KH}_{2} \mathrm{PO}_{4}(+\mathrm{P})$ or $20 \mathrm{ml}$ of distilled water $(-\mathrm{P})$, thoroughly mixed, and packed to a bulk density of $1.2 \mathrm{~g} \mathrm{~cm}^{-3}$. The chambers were placed in plastic bags and stored at $4{ }^{\circ} \mathrm{C}$ until they were placed in the field.

In each plot, 12 chambers constructed using soil from that plot, were installed (three of each treatment: $+\mathrm{R}+\mathrm{P}$, $+\mathrm{R}-\mathrm{P},-\mathrm{R}+\mathrm{P}$, and $-\mathrm{R}-\mathrm{P}$ ) at the VT stage of maize on 15 July at Shelton and 13 July at Lincoln. The chambers were buried so that the upper edge was $5 \mathrm{~cm}$ below the soil surface.

\subsection{Removal of chambers and field sampling}

Four chambers $(+\mathrm{R}+\mathrm{P}, \quad+\mathrm{R}-\mathrm{P}, \quad-\mathrm{R}+\mathrm{P}, \quad$ and $-\mathrm{R}-\mathrm{P}$ ) were removed from each plot (Shelton, $n=12$; Lincoln, $n=8$ ) three, six, and nine weeks after installation (4 and 23 August and 13 September at Shelton and 3 and 26 August and 16 September at Lincoln). Ten soil cores (0- to $15-\mathrm{cm}$ depth) were taken adjacent to the chambers and combined on each date that chambers were removed. Additional soil samples were taken at Shelton at V6 and R1-2. The chambers and the composite soil samples were transported in a cooler to the laboratory, where chambers where opened. The soil was passed through a $4 \mathrm{~mm}$ sieve to remove visible organic residues, thoroughly mixed, and divided in two subsamples. One subsample was air dried for Bray $\mathrm{P}$ analysis, and the other was stored at $-18^{\circ} \mathrm{C}$ until they were analyzed for AM fatty acid biomarkers.

\subsection{AM biomarker quantification and identification}

Mycorrhizae were quantified using fatty acid biomarkers released by mild alkaline hydrolysis of the soil (Drijber et al., 2000; Schutter and Dick, 2000). This process does not methylate free fatty acids, but only ester-linked fatty acids (Kates, 1986; Grogan and Cronan, 1997). Briefly, $5 \mathrm{~g}$ soil in $50 \mathrm{ml}$ Teflon centrifuge tubes were hydrolyzed with $10 \mathrm{ml}$ freshly prepared $0.2 \mathrm{M}$ potassium hydroxide in methanol at $37^{\circ} \mathrm{C}$ for $1 \mathrm{~h}$ with shaking of the tubes every $10 \mathrm{~min}$. Alkaline extracts were neutralized with $1 \mathrm{ml} 1 \mathrm{M}$ acetic acid and FAMEs were partitioned into $5 \mathrm{ml}$ hexane followed by centrifuging at $3470 \times g$ for $10 \mathrm{~min}$. The hexane layer was then transferred to a $15 \mathrm{ml}$ Pyrex tube and the aqueous-soil mixture re-extracted with another $5 \mathrm{ml}$ hexane. Hexane extracts were combined and filtered through an Acrodisc ${ }^{\mathbb{R}}$ CR $13 \mathrm{~mm}$ syringe filter with $0.2 \mu \mathrm{m}$ PTFE membrane into a clean $15 \mathrm{ml}$ Pyrex tube. The hexane was then evaporated under $\mathrm{N}_{2}$ and the lipid residue redissolved into $500 \mu \mathrm{l}$ hexane containing $0.05 \mu \mathrm{g} \mathrm{l}^{-1}$ methylnonadecanoate as the internal standard.

Released FAMEs were separated by gas chromatography, using helium as a carrier gas, and an Ultra 2 HP $(50 \mathrm{~m}, 0.2 \mathrm{~mm}$ I.D., $0.33 \mu \mathrm{m}$ film thickness) capillary column. The gas chromatograph was run in split mode (44:1) with a $45 \mathrm{~s}$ purge time. Injector and flame ionization detectors were maintained at 280 and $300^{\circ} \mathrm{C}$, respectively, and oven temperature was ramped from 50 to $160^{\circ} \mathrm{C}$ at $40{ }^{\circ} \mathrm{C} \mathrm{min}{ }^{-1}$ and held for $2 \mathrm{~min}$, then ramped at $3{ }^{\circ} \mathrm{C} \mathrm{min}^{-1}$ to $300^{\circ} \mathrm{C}$ and held for $30 \mathrm{~min}$. The fatty acids were identified by retention time and confirmed by mass spectrometry. Concentrations of FAMEs were calculated from peak areas relative to the internal standard and reported as nmol g ${ }^{-1}$ soil.

Fatty acids were designated as the total number of $\mathrm{C}$ atoms followed by a colon, the number of double bonds followed by the position of the double bond from the carboxyl end of the molecule and its cis or trans configuration (IUPAC-UIB, 1987). The FAMEs selected as mycorrhizal biomarkers were C16:1 cis11 (Olsson and Johansen, 2000) and C18:1cis11 (Olsson, 1999). Although, C18:1cis 11 is common to several gram negative bacteria, C16:1 cis 11 is found in only a few bacterial genera (Zelles, 1999).

\subsection{AM biomarker concentration in selected lipid classes from Shelton chambers}

A modified one-phase extraction procedure of Bligh and Dyer (White et al., 1979) was used to extract lipids from soil at Shelton. Soil $(10 \mathrm{~g})$ from two randomly selected chambers $+\mathrm{R},-\mathrm{P}$ from three dates, 4 August, 23 August and 13 September, was extracted with chloroform-methanol $\left(1: 1 \mathrm{vol} \mathrm{vol}^{-1}\right)$ and separated into neutral lipid fatty acids (NLFA), glycolipid fatty acids (GLFA) and PLFA classes by silica gel chromatography (Drijber et al., 2000). Fatty acids were saponified and quantified as described above for FAMEs.

\subsection{Statistical analysis}

Statistical analyses were performed using SAS (SAS Inst., 1999) and differences were declared significant at the 0.05 level unless stated otherwise. At Shelton, analysis of variance was performed to test for differences in fatty acid concentration and Bray $\mathrm{P}$ in soil samples for a complete randomized design with $\mathrm{ECa}$ class as treatment factors (Johnson et al., 2001). The chamber experiment was analyzed as a split plot in time and space, with EC as the whole plot in a complete randomized design. At Lincoln, field soil was tested with a complete randomized block design. The chamber experiment was analyzed as a split plot in time and space, with fertility treatment as the whole plot in a complete randomized block design. Seasonal and treatment differences between the absolute amounts of 
individual fatty acids and Bray $\mathrm{P}$ were evaluated using repeated-measures mixed model ANOVA. As the correlation between observations did not follow a clear pattern over time, compound symmetry covariance structure was used in the repeated-measures mixed model ANOVA. The ANOVA tables are described at the beginning of each section.

\section{Results}

\subsection{Properties of soil used to construct chambers}

Bulk soil collected from field sites at Shelton and Lincoln differed in available $\mathrm{P}$ and $\mathrm{AM}$ biomarker concentration. At Shelton, Bray and organic P were lower in ECa II than ECa IV (Table 1). At Lincoln, M1 had lower Bray and organic P than M2 (Table 1). FAME biomarker concentration was inversely related to available $\mathrm{P}$.

\subsection{Dynamics of AM fungal biomarkers in field soil}

The concentration of $\mathrm{C} 16: 1$ cis 11 and $\mathrm{C} 18: 1$ cis 11 biomarkers over time from Shelton and Lincoln field soil are reported in Table 2. At Shelton, the main factor 'ECa' and

Table 1

Concentration of C16:1cis11 FAME biomarker and availability of $\mathrm{P}$ in soil samples from Shelton and Lincoln used to make the chambers

\begin{tabular}{lllll}
\hline Field & Treatment & $\begin{array}{l}\text { C16:1cis11 } \\
\left(\mathrm{nmol} \mathrm{g}^{-1}\right. \\
\text { soil) }\end{array}$ & $\begin{array}{l}\text { Bray P } \\
\left(\mathrm{mg} \mathrm{kg}^{-1}\right. \\
\text { soil) }\end{array}$ & $\begin{array}{l}\text { Organic P } \\
\left(\mathrm{mg} \mathrm{kg}^{-1}\right. \\
\text { soil) }\end{array}$ \\
\hline Shelton & ECa class II & 5.25 & 13.26 & 115.30 \\
& ECa class IV & 3.63 & 41.93 & 126.82 \\
Lincoln & M1 & 2.19 & 57.59 & 191.18 \\
& M2 & 2.07 & 84.06 & 235.59 \\
\hline
\end{tabular}

ECa class II = apparent electrical conductivity class II; ECa class IV = apparent electrical conductivity class IV; $\mathrm{M} 1=$ recommended nutrient management and $\mathrm{M} 2=$ intensive nutrient management. the interaction ' $\mathrm{ECa} *$ time' were not significant for both biomarkers. At Lincoln, the main factor 'fertility' (M1 vs. M2) was significant $(P=0.04)$ for $\mathrm{C} 16: 1$ cis 11 , and the interaction 'fertility $*$ time' was not. The mean concentration of C16:1cis 11 decreased from $3.42 \pm 0.15 \mathrm{nmol} \mathrm{g}^{-1}$ in M1 to $2.88 \pm 0.15 \mathrm{nmol} \mathrm{g}^{-1}$ soil in M2. For C18:1cis11, only the main factor 'time' was significant.

The FAME biomarker C16:1cis11 increased from August to September at Shelton and from July to September at Lincoln (Table 2). This increase demonstrates transport of $\mathrm{C}$ from the plant to the fungal symbiont during the reproductive stages of maize. At both sites, C18:1 cis11 increased from August to September. Field samples from Shelton showed a higher concentration of AM FAME biomarkers than samples from Lincoln.

\subsection{Dynamics of AM fungal biomarker in chamber soils}

Chamber mesh size effectively excluded or allowed root passage into the soil chambers. Roots were found in the $+\mathrm{R}$ chambers three weeks after VT at Shelton and Lincoln. We observed roots on the outer walls of $-\mathrm{R}$ chambers, but none penetrated the mesh.

The concentration of $\mathrm{C} 16: 1$ cis 11 and $\mathrm{C} 18: 1$ cis 11 biomarkers in chamber soil over time are reported in Table 3. At Shelton, the main factors 'time' $(P=0.01)$, 'ECa' $(P=$ $0.01)$ and 'mesh size' $(+\mathrm{R},-\mathrm{R})(P=0.02)$ were significant for $\mathrm{C} 16: 1$ cis 11; the addition of $\mathrm{P}(+\mathrm{P},-\mathrm{P})$ and the interactions among these factors were not significant. For C18:1 cis 11, the main factors 'mesh size' and 'time', and the interaction 'mesh $*$ time' $(P=0.01)$ were significant. At Lincoln the main factor 'time' was significant for C16:1cis11, while $\mathrm{P}$ addition, mesh size, nutrient management or the interactions among them were not significant. The main factor 'time' was marginally significant for C18:1cis11 $(P=0.07)$ and significant for mesh size $(P=0.04)$.

At Shelton, C16:1cis11 increased inside the chambers from VT onwards (Table 3). The addition of $\mathrm{P}$ to the chambers had no effect on the concentration of C16:1 cis 11 or $\mathrm{C} 18: 1$ cis 11 over time. However, the $+\mathrm{R}$ chambers had

Table 2

Concentration of C16:1cis11 and C18:1cis11 FAME biomarkers in field soil

\begin{tabular}{|c|c|c|c|c|c|}
\hline & $\begin{array}{l}19 \text { June } \\
\text { (nmolg g }{ }^{-1} \text { soil) }\end{array}$ & $\begin{array}{l}15 \text { July } \\
\left(\mathrm{nmol} \mathrm{g}^{-1} \text { soil) }\right.\end{array}$ & $\begin{array}{l}4 \text { August } \\
\left(\mathrm{nmolg}^{-1} \text { soil) }\right.\end{array}$ & $\begin{array}{l}23 \text { August } \\
\left(\mathrm{nmolg}^{-1} \text { soil) }\right.\end{array}$ & $\begin{array}{l}13 \text { September } \\
\left(\mathrm{nmolg}^{-1} \text { soil }\right)\end{array}$ \\
\hline \multicolumn{6}{|l|}{ Shelton } \\
\hline \multirow[t]{2}{*}{$\mathrm{C} 18: 1$ cis 11} & $9.58 \mathrm{~b}$ & $10.34 \mathrm{~b}$ & $10.7 b$ & $10.62 \mathrm{~b}$ & $11.96 \mathrm{a}$ \\
\hline & & $\begin{array}{l}15 \text { July (nmol g } \\
\text { soil) }\end{array}$ & $\begin{array}{l}3 \text { August (nmol g-1 } \\
\text { soil) }\end{array}$ & $\begin{array}{l}26 \text { August } \\
\left(\mathrm{nmolg}^{-1} \text { soil) }\right.\end{array}$ & $\begin{array}{l}\text { 16 September } \\
\left(\mathrm{nmol} \mathrm{g}^{-1} \text { soil) }\right.\end{array}$ \\
\hline C16:1cis 11 & & $2.21 \mathrm{~d}$ & $2.67 \mathrm{c}$ & $3.21 \mathrm{~b}$ & $4.51 \mathrm{a}$ \\
\hline $\mathrm{C} 18: 1$ cis 11 & & $5.22 \mathrm{~b}$ & $5.64 b$ & $5.61 \mathrm{~b}$ & $6.76 \mathrm{a}$ \\
\hline
\end{tabular}

Means followed by the same letter within a row are not different $(P<0.05)$. 
Table 3

Concentration of C16:1cis11 and C18:1cis11 FAME biomarkers in chamber soil

\begin{tabular}{|c|c|c|c|}
\hline & $\begin{array}{l}4 \text { August } \\
\text { (nmol g } \\
\text { soil) }\end{array}$ & $\begin{array}{l}23 \text { August } \\
\text { (nmol g-1 } \\
\text { soil) }\end{array}$ & $\begin{array}{l}13 \text { September } \\
\left(\mathrm{nmolg}^{-1}\right. \\
\text { soil) }\end{array}$ \\
\hline \multicolumn{4}{|l|}{ Shelton } \\
\hline $\mathrm{C} 16: 1$ cis 11 & $3.81 \mathrm{~b}$ & $4.18 b$ & $5.9 \mathrm{a}$ \\
\hline $\mathrm{C} 18: 1 \operatorname{cis} 11+\mathrm{R}^{*}$ & $7.7 \mathrm{~b}$ & $8.34 \mathrm{~b}$ & $11.02 \mathrm{a}$ \\
\hline \multirow[t]{2}{*}{$\mathrm{C} 18: 1 \operatorname{cis} 11-\mathrm{R}$} & $7.61 \mathrm{a}$ & $7.79 \mathrm{a}$ & $8.84 \mathrm{a}$ \\
\hline & $\begin{array}{l}3 \text { August } \\
\text { (nmol g } \\
\text { soil) }\end{array}$ & $\begin{array}{l}26 \text { August } \\
\text { (nmolg g } \\
\text { soil) }\end{array}$ & $\begin{array}{l}16 \text { September } \\
\left(\mathrm{nmol} \mathrm{g}^{-1}\right. \\
\text { soil) }\end{array}$ \\
\hline \multicolumn{4}{|l|}{ Lincoln } \\
\hline C16:1cis 11 & $1.84 \mathrm{~b}$ & $2.14 \mathrm{~b}$ & $3.08 \mathrm{a}$ \\
\hline $\mathrm{C} 18: 1 \operatorname{cis} 11^{* *}$ & $4.95 \mathrm{~b}$ & $5.04 \mathrm{ab}$ & $5.36 \mathrm{a}$ \\
\hline
\end{tabular}

Means followed by the same letter within a row are not different $(P<0.05)$.

${ }^{*}$ C18:1 cis11 FAME biomarker at Shelton: significant mesh $*$ time $(P=$ $0.02)$ interaction. Rings enclosed with a $1 \mathrm{~mm}$ mesh fabric to allow $(+\mathrm{R})$ or $0.04 \mathrm{~mm}$ mesh fabric to exclude $(-\mathrm{R})$ maize roots. Means followed by the same letter are not different $(P<0.05)$.

${ }^{* *} P=0.07$.

an $11 \%$ higher $\mathrm{C} 16: 1$ cis 11 marker concentration than in the $-\mathrm{R}$ chambers. We also observed that $\mathrm{C} 16: 1$ cis 11 was $36 \%$ greater in ECa class II than class IV. The concentration of $\mathrm{C} 18: 1$ cis 11 showed a 'mesh $*$ time' interaction (Table 3). This interaction resulted from similar concentration of the biomarker in chambers at the first and second sample times but greater biomarker concentration in $+\mathrm{R}$ than $-\mathrm{R}$ on 13 September. The increase in C18:1 cis11 in $+\mathrm{R}$ chambers in September mirrored the increase in C16:1cis11 over time; however, the proportional increase in $\mathrm{C} 18: 1$ cis 11 was greater than that for $\mathrm{C} 16: 1$ cis 11 , possibly related to the influence of gram negative bacteria on the concentration of $\mathrm{C} 18: 1$ cis 11 in rhizosphere soil.

At Lincoln, C16:1cis11 was greater on 16 September than on earlier sampling dates (Table 3). In this field, there were no differences in $\mathrm{C} 16: 1$ cis 11 concentration due to mesh size or soil $\mathrm{P}$ availability. The C18:1cis11 biomarker also increased over time $(P=0.07)$, and had a higher concentration at M1 sites $\left(5.22 \pm 0.13 \mathrm{nmol} \mathrm{g}^{-1}\right.$ soil $)$ than M2 sites $\left(5.01 \pm 0.13 \mathrm{nmol} \mathrm{g}^{-1}\right.$ soil).

When comparing the concentration of the C16:1cis 11 biomarker over time in the chambers to that in the field soil, we observed a lower initial concentration of this marker in the chambers and a slower rate of increase over time. The soil used to assemble the chambers was sieved, stored in the refrigerator (before and after chamber assembly), packaged into chambers, and in some cases amended with P. This manipulation possibly caused a loss and/or alteration of AM structures during soil processing. Field samples had a $22 \%$ (Shelton) or $32 \%$ (Lincoln) higher concentration of C16:1cis11 (mean of the three sampling dates) compared to the chambers.

\subsection{Dynamics of $P$ availability in soil chambers}

The addition of $\mathrm{P}$ to the chambers increased the amount of available $\mathrm{P}$ for both Shelton and Lincoln (Table 4). For Shelton chambers without additional $\mathrm{P}(-\mathrm{P})$, available $\mathrm{P}$ was significant for the main factors ' $\mathrm{ECa}$ ' and 'time', and was not significant for mesh size, or the interactions among these factors. The concentration of Bray $\mathrm{P}$ was $14.5 \mathrm{mg} \mathrm{kg}^{-1}$ soil $\pm 2.5 \mathrm{mg} \mathrm{kg}^{-1}$ soil for ECa II and $38.0 \pm$ 2.5 for ECa IV. Similarly, in chambers with additional $\mathrm{P}$ $(+\mathrm{P})$ the significant factors were ' $\mathrm{ECa}$ ' and 'time'. The concentration of Bray $\mathrm{P}$ was $22.9 \mathrm{mg} \mathrm{kg}^{-1}$ soil \pm 3.6 for ECa II and $49.3 \mathrm{mg} \mathrm{kg}^{-1}$ soil \pm 3.6 for ECa IV. At Lincoln, available $\mathrm{P}$ in chambers without additional $\mathrm{P}(-\mathrm{P})$ was significant for the main factors 'mesh size' and 'time' and the interactions 'fertility $*$ mesh' $\quad(P=0.04)$ and 'mesh $*$ time' $(P=0.04)$. For the chambers with additional $\mathrm{P}(+\mathrm{P})$ the ANOVA showed no significant differences.

We did not observe an increase in available $\mathrm{P}$ when comparing the soil used to make the chambers and the soil from the first sampling date in $-\mathrm{P}$ chambers at Shelton or Lincoln, demonstrating that soil manipulation (sieving, storage in refrigerator, packaging) did not enhance $\mathrm{P}$ mineralization (Tables 1 and 4). At Shelton, available P inside the chambers decreased from August to September (Table 4). Phosphorous availability was not influenced by mesh size, thus AM fungi ( $-\mathrm{R}$ chambers) appeared as effective as roots plus mycorrhizae $(+\mathrm{R}$ chambers) in reducing chamber $\mathrm{P}$ concentration.

In $-\mathrm{P}$ chambers at Lincoln, there was a 'mesh $*$ time' interaction (Table 4). There was an increase in available $P$ on 26 August in the $+\mathrm{R}$ chambers that was not observed in the $-\mathrm{R}$ chambers. A 'site $*$ mesh' interaction was also observed due to an increase in $\mathrm{P}$ availability in the $-\mathrm{R}, \mathrm{M} 2$ site. In this field, the availability of $\mathrm{P}$ in $+\mathrm{P}$ chambers was similar over time.

Table 4

Availability of $\mathrm{P}$ in chamber soil

\begin{tabular}{|c|c|c|c|}
\hline & $\begin{array}{l}4 \text { August } \\
\left(\mathrm{mg} \mathrm{kg}^{-1} \text { soil }\right)\end{array}$ & $\begin{array}{l}23 \text { August } \\
\left(\mathrm{mg} \mathrm{kg}^{-1} \text { soil }\right)\end{array}$ & $\begin{array}{l}13 \text { September } \\
\left(\mathrm{mg} \mathrm{kg}^{-1} \text { soil }\right)\end{array}$ \\
\hline \multicolumn{4}{|l|}{ Shelton } \\
\hline$+\mathrm{P}$ chambers & $38.73 \mathrm{a}$ & $37.23 \mathrm{a}$ & $32.3 b$ \\
\hline \multirow[t]{2}{*}{$-\mathrm{P}$ chambers } & $27.35 \mathrm{a}$ & $27.53 \mathrm{a}$ & $24.0 \mathrm{~b}$ \\
\hline & $\begin{array}{l}3 \text { August } \\
\left(\mathrm{mg} \mathrm{kg}^{-1} \text { soil) }\right.\end{array}$ & $\begin{array}{l}26 \text { August } \\
\left(\mathrm{mg} \mathrm{kg}^{-1} \text { soil) }\right.\end{array}$ & $\begin{array}{l}16 \text { September } \\
\left(\mathrm{mg} \mathrm{kg}^{-1} \text { soil }\right)\end{array}$ \\
\hline \multicolumn{4}{|l|}{ Lincoln } \\
\hline$+\mathrm{P}$ chambers & $84.51 \mathrm{a}$ & $85.98 \mathrm{a}$ & $83.22 \mathrm{a}$ \\
\hline$-\mathrm{P},+\mathrm{R}$ chambers ${ }^{*}$ & $68.47 \mathrm{~b}$ & $74.57 \mathrm{a}$ & $70.14 b$ \\
\hline$-\mathrm{P},-\mathrm{R}$ chambers & $70.98 \mathrm{a}$ & $74.36 \mathrm{a}$ & $71.26 \mathrm{a}$ \\
\hline
\end{tabular}

Means followed by the same letter within a row are not different $(P<0.05)$.

${ }^{*}$-P chambers at Lincoln: significant mesh $*$ time $(P=0.04)$ interaction. Rings enclosed with a $1 \mathrm{~mm}$ mesh fabric to allow $(+\mathrm{R})$ or $0.04 \mathrm{~mm}$ mesh fabric to exclude $(-\mathrm{R})$ maize roots. Means followed by the same letter within a row are not different $(P<0.05)$. 


\subsection{AM fungal biomarker distribution in $+R-P$ chambers at Shelton}

There was an increase in the total concentration of AM fungal biomarker C16:1cis11 (measured as the addition of C16:1 cis11 in the NLFA, GLFA and PLFA lipid classes) over time at Shelton. The concentration of PLFA C16:1cis11 was similar for the three sampling dates. Although mean concentrations of C16:1cis 11 increased over time for both the NLFA and GLFA fractions, they were not significant. However, when summed, the mean concentrations increased significantly over time. The combined concentration of the NLFA and GLFA fractions was $204 \%$ higher in September than the mean of the August sampling dates. In addition, the relative contribution of these two fractions to total C16:1 cis 11 was $52 \%$ in August, and $76 \%$ in September.

\section{Discussion}

\subsection{Concentration of AM fungal biomarkers in field soil and chambers}

Mycorrhizal colonization of soil and plant roots is a complex multi-step process, in which the mycorrhizal association is influenced not only by the host plant and the AM fungi, but also by soil and other environmental conditions (Barea, 1991). The higher concentration of C16:1cis11 found in field samples from Shelton, when compared to Lincoln, may stem from differences in soil type and the lower P availability (Bray P and organic P) at Shelton. Although $\mathrm{P}$ availability may be responsible for decreased concentrations of AM biomarkers at Shelton ECa IV and Lincoln M2 sites, the higher availability of N in Lincoln M2 may also contribute to the reduction in C16:1 cis11. In spring 2003, the 0 - to $30-\mathrm{cm}$ surface layer contained 8.9 and $31.2 \mathrm{~kg}$ of $\mathrm{NO}_{3}-\mathrm{N} \mathrm{ha}^{-1}$, for $\mathrm{M} 1$ and $\mathrm{M} 2$, respectively (A. Dobermann, personal communication, 2006). Liu et al. (2000) studied the influence of soil $\mathrm{N}$ and $\mathrm{P}$ levels in three maize hybrids. After two months, $\mathrm{P}$ application decreased the percentage of AM colonization, the fungal colonization had a negative interaction with $\mathrm{N}$ application and was affected by the hybrid. Bradley et al. (2006) studied soil microbial response to $\mathrm{N}$ fertilization throughout time in a grassland ecosystem. They found that mycorrhizal FAME biomarkers decreased in response to anthropogenic $\mathrm{N}$ long before responses were evident in plant communities.

A second factor could be the presence of AM species that differ in their responses to cropping history and edaphic factors. Johnson et al. (1991) attributed the large difference in evenness of AM communities between two sites to differences in soil cultural practices. The frequency and intensity of the tillage practices at Shelton and Lincoln are different. Soil disturbance by fall plowing, as is practiced at Lincoln, was shown to reduce over-winter survival of hyphae and mycorrhizal potential, probably as a conse- quence of physical disruption of roots and hyphal network (Kabir et al., 1997).

A third factor may be plant genotype. Liu et al. (2003) showed that $\mathrm{P}$ uptake by AM fungi in maize was strongly hybrid dependant. Furthermore, carbohydrate allocation was shown to affect colonization rate in citrus and this process apparently was controlled by plant genotypes (Graham et al., 1991; Graham and Eissenstat, 1998). Thus, the different maize hybrids used at Shelton and Lincoln may have different affinity for AM fungi.

The concentration of AM biomarkers in field samples was greater than in chambers for all dates and sites. This was probably due to disturbance of the soil before assembling the chambers, and the cost attributed to the formation of a new hyphal network inside these chambers. Disturbance reduces total hyphal density, metabolically active hyphal density, and the proportion of hyphae that is viable (Kabir et al., 1997). The mycelial network appears to be an important component of the inoculum potential in undisturbed soil, and its disturbance effects mycorrhizal colonization and $\mathrm{P}$ absorption (Evans and Miller, 1990; Miller, 2000). Alternatively, in field soil where the hyphal network was disturbed prior to V6 by field operations, AM fungi would exist in several growth stages and the development of specialized structures, or accumulation of storage lipids could account for the higher biomarker concentrations than in chambers.

\subsection{Evidence for $C$ allocation to $A M$ fungi during reproductive growth of maize}

In field soils at both sites, C16:1cis 11 increased during the reproductive growth stages of the crop. A parallel increase in C18:1cis11 occurred only during the later reproductive growth stages. Both of these FAME biomarkers are indicative of $\mathrm{AM}$ fungi, although $\mathrm{C} 18: 1$ cis 11 , and to a lesser extent C16:1cis11, are found in bacteria. Although net increase in AM biomarkers could arise from reallocation of $\mathrm{C}$ within the fungal network, a more likely immediate source would be the plant. This is supported by AM fungal colonization of the soil chambers installed just prior to the reproductive stages of growth.

Preparation of the chambers with bulk field soil would have thoroughly disrupted the mycelial network of existing AM fungi in the field leaving only mycelial fragments and spores as inoculum for the current maize crop. This inoculum would be subject to degradation over time leading to declining amounts of the AM fungal biomarker C16:1 cis11 in the absence of a host plant. Thus, any net increase in the AM fungal marker is evidence for hyphal penetration of the chamber $(-\mathrm{R}$ or $+\mathrm{R})$ from adjacent field soil or successful spore germination and hyphal growth (in terms of establishment of the plant-fungi symbiosis), and the formation of arbuscules and vesicles within the root structure in $+\mathrm{R}$ chambers.

Olsson (1999) reviewed the signature fatty acid composition of lipids in mycorrhizal fungi and stated that in most 
fungi, a large proportion of the total fatty acids are found as $\mathrm{C} 16: 1$ cis 11 and $\mathrm{C} 18: 1$ cis 11 . In our study, a positive correlation was observed between these two AM biomarkers for both field and chamber soils. At Shelton, the correlation for field soil was $r=0.78(P=0.01)$ and for chamber soil was $r=0.66(P=0.01)$, while at Lincoln lower correlations were observed (field soil, $r=0.38, P=$ 0.02 and chamber soil, $r=0.35, P=0.01)$. Although C16:1cis11 and C18:1cis11 appear to be complementary markers for AM fungal dynamic in soils, gram negative bacteria would contribute significantly to the C18:1 cis 11 biomarker pool (Zelles, 1999).

\subsection{Distribution of AM fungal biomarkers among lipid classes}

Two important types of lipids found in fungi are phospholipids (membrane constituents) and neutral lipids (energy storage). Both contain ester-linked fatty acids to a glycerol backbone (Olsson, 1999). Extraction of FAMEs by mild alkaline hydrolysis includes both these lipid pools, in addition to glycolipid-linked fatty acids. The AM biomarker C16:1cis11 clearly increased over time in the NLFA and GLFA fractions (Fig. 1) and is likely the source of increased C16:1cis11 extracted by mild alkaline hydrolysis.

Gavito and Olsson (2003) observed that allocation of C to hyphal proliferation or storage lipids in AM fungi was related to plant variations in both nutrient supply and plant $\mathrm{C}$ availability. Fungal lipids present in the external mycelium are derived from $\mathrm{C}$ taken up as hexose by the fungal tissues within the host root (Pfeffer et al., 1999). The AM fungi convert these sugars into lipids that are then translocated to the extraradical mycelium in lipid bodies.

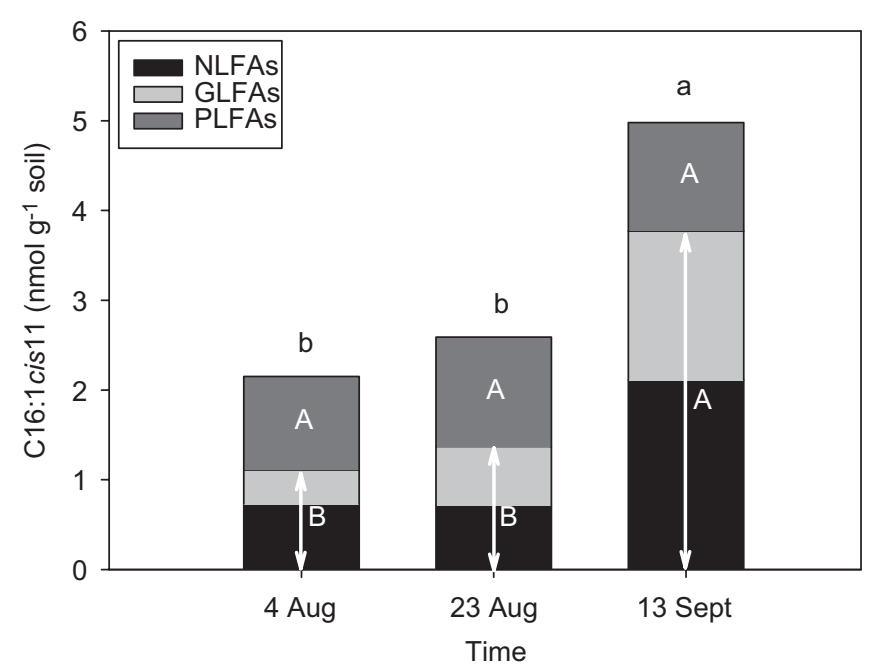

Fig. 1. Concentration of chloroform methanol extracted C16:1cis11 over time in Shelton $(+\mathrm{R},-\mathrm{P})$ chambers. Bars followed by the same letter are not different among dates $(P<0.05)$. Capital letters are used to compare PLFA and the combined concentration of NLFA and GLFA. Lower case letters represent differences among the addition of the three fractions.
Up to $50 \%$ of the hyphal volume may be lipid bodies (Bago et al., 2000). Using ${ }^{13} \mathrm{C}$ as a tracer, Pfeffer et al. (1999) demonstrated ${ }^{13} \mathrm{C}$ enrichment of NLFA C16:1cis11 in mycelium. This indicates that lipids are the main $\mathrm{C}$ compounds translocated in AM fungal mycelia. Olsson and Johansen (2000) observed that the proportion of neutral lipids in old AM cultures was found to be higher in external mycelium than in internal mycelium. They conclude that neutral lipids accumulate in old mycelium as energy storage products, possibly preceding the sporulation processes. The neutral lipids within the extramatrical hyphae would largely coincide with cytoplasmic regions of the hyphae bound by phospholipid membranes.

Our study confirmed that, even if the biomarker comes from hyphae, and branched structures in the $-\mathrm{R}$ chambers, or arbuscules and vesicles in the $+\mathrm{R}$ ones, the plant has allocated $\mathrm{C}$ to the fungus after tasselling. Clearly there is an important functional difference if this marker comes from storage structures or from external functional structures (i.e. absorptive hyphae), and these issues should be elucidated in future studies.

\subsection{AM fungal colonization of chambers and available $P$}

A large proportion of $\mathrm{P}$ uptake by maize occurs during the reproductive period (Karlen et al., 1988), while approximately three weeks after tasselling root biomass reaches a maximum (Plenet, 1995). The reduction in available $\mathrm{P}$ inside the $+\mathrm{R}$ and $-\mathrm{R}$ chambers from August to September at Shelton was likely due to hyphal-mediated $\mathrm{P}$ uptake and coincided with accumulation of C16:1cis11 within the NLFA and GLFA fractions. High P availability has been shown to reduce $\mathrm{C}$ allocation to AM fungi (Olsson et al., 1997) and reduce extraradical hyphal growth and spore germination (De Miranda and Harris, 1994; Liu et al., 2000). However, this does not necessarily imply a lower contribution by AM fungi to total P uptake ( $\mathrm{Li}$ et al., 2006). In our study, high soil $P$ availability did not prevent hyphal colonization of the chambers suggesting that the $\mathrm{P}$ status of the plant may be more influential in determining allocation of C to AM fungi (Graham et al., 1997).

\section{Conclusions}

We conclude that the influence of soil $\mathrm{P}$ availability on AM fungal development may be dependent on maize $\mathrm{P}$ status and its linkage to crop physiological signals. The increase in the AM biomarker concentration in field soil and in chambers during the reproductive stages of maize confirmed the allocation of $\mathrm{C}$ from the plant to the mycorrhizal symbiont. Since root biomass does not change from two to three weeks after tasselling to maturity, AM fungi may play an essential role in $\mathrm{P}$ uptake of maize later in the growing season. Chambers that allowed only passage of AM hyphae were as efficient as roots and AM hyphae in extracting $\mathrm{P}$ from soil within the chambers. Further work is needed to identify mechanisms controlling the temporal 
allocation of $\mathrm{C}$ from plant to $\mathrm{AM}$ fungus, and the mycorrhizal contribution to $\mathrm{P}$ uptake during the reproductive stages of maize. The dynamics of lipid accumulation and formation of specialized structures in AM fungi appears to be essential to this process.

\section{Acknowledgments}

We want to express our gratitude to Liz Jeske, Susan Siragusa, Josh Cool, Sarah Berg, Susan Wagner for their essential help in the laboratory and in the field.

\section{References}

Bago, B., Pfeffer, P.E., Shachar-Hill, Y., 2000. Update on symbiosis. Carbon metabolism and transport in arbuscular mycorrhizas. Plant Physiology 124, 949-957.

Barber, S.A., 1977. Application of phosphate fertilizers: methods, rates and time of application in relation to the phosphorus status of soils. Phosphorus in Agriculture 70, 109-115.

Barea, J.M., 1991. Vesicular-arbuscular mycorrhizae as modifiers of soil fertility. In: Stewart, B.A. (Ed.), Advances in Soil Science, vol.16. Springer, NY, pp. 8-18.

Bradley, K., Drijber, R.A., Knopps, J., 2006. Increased N availability in grassland soils modifies their microbial communities and decreases the abundance of arbuscular mycorrhizal fungi. Soil Biology \& Biochemistry $38,1583-1595$.

Bray, R.H., Kurtz, L.T., 1945. Determination of total, organic and available forms of phosphorus in soils. Soil Science 59, 39-45.

De Miranda, J.C.C., Harris, P.J., 1994. Effects of soil phosphorous on spore germination and hyphal growth of arbuscular mycorrhizal fungi. New Phytologist 128, 103-108.

Drijber, R.A., Doran, J.W., Parkhurst, A.M., Lyon, D.J., 2000. Changes in soil microbial community structure with tillage under long-term wheat-fallow management. Soil Biology \& Biochemistry 32, 1419-1430.

Evans, D.G., Miller, M.H., 1990. The role of the external mycelial network in the effect of soil disturbance upon vesicular-arbuscular mycorrhizal colonization of maize. New Phytologist 114, 65-71.

Gavito, M.E., Olsson, P.A., 2003. Allocation of plant carbon to foraging and storage in arbuscular mycorrhizal fungi. FEMS Microbiology Ecology 45, 181-187.

Graham, J.H., Eissenstat, D.M., 1998. Field evidence for the carbon cost of citrus mycorrhizas. New Phytologist 140, 103-110.

Graham, J.H., Eissenstat, D.M., Drouillard, D.L., 1991. On the relationship between a plant's mycorrhizal dependency and rate of vesiculararbuscular mycorrhizal colonization. Functional Ecology 5, 773-779.

Graham, J.H., Hodge, N.C., Morton, J.B., 1995. Fatty acid methyl ester profiles for characterization of Glomalean fungi and their endomycorrhizae. Applied and Environmental Microbiology 61, 58-64.

Graham, J.H., Duncan, L.W., Eissenstat, D.M., 1997. Carbohydrate allocation patterns in citrus genotypes as affected by phosphorous nutrition, mycorrhizal colonization and mycorrhizal dependency. New Phytologist 135, 335-343.

Grant, C.A., Flaten, D.N., Tomasiewicz, D.J., Sheppard, S.C., 2001. The importance of early season phosphorus nutrition. Canadian Journal of Plant Science 81, 211-224.

Grigera, M.S., Drijber, R.A., Eskridge, K.M., Wienhold, B.J., 2006. Soil microbial biomass relationships with organic matter fractions in a Nebraska corn field mapped using apparent electrical conductivity. Soil Science Society of America Journal 70, 1480-1488.

Grogan, D.W., Cronan Jr., J.E., 1997. Cyclopropane ring formation in membrane lipids of bacteria. Microbiology and Molecular Biology Reviews 61, 429-441.
Gryndler, M., Larsen, J., Hršelová, H., Řezáčová, V., Gryndlerová, H., Kubát, J., 2006. Organic and mineral fertilization, respectively, increase and decrease the development of external mycelium of arbuscular mycorrhizal fungi in a long-term field experiment. Mycorrhiza 16, 159-166.

IUPAC-UIB, 1987. The nomenclature of lipids. Journal of Lipid Research 19, 114-128.

Johnson, C.K., Doran, J.W., Duke, H.R., Wienhold, B.J., Eskridge, K.M., Shanahan, J.F., 2001. Field-scale electrical conductivity mapping for delineating soil condition. Soil Science Society of America Journal 65, 1829-1837.

Johnson, N.C., Pfleger, F.L., Crookston, R.K., Simmons, S.R., Copeland, P.J., 1991. Vesicular-arbuscular mycorrhizas respond to corn and soybean cropping history. New Phytologist 117, 657-663.

Kabir, Z., O'Halloran, I.P., Hamel, C., 1997. Overwinter survival of arbuscular mycorrhizal hyphae is favored by attachment to roots but diminished by disturbance. Mycorrhiza 7, 197-200.

Karlen, D.L., Flannery, R.L., Sadler, E.J., 1988. Aerial accumulation and partition of nutrients by corn. Agronomy Journal 80, 232-242.

Kates, M., 1986. Techniques of lipidology: isolation, analysis and identification of lipids. In: Burdon, R.H., vanKippenberg, P.H. (Eds.), Laboratory Techniques in Biochemistry and Molecular Biology, vol. 3, Part 2. Elsevier, NY, pp. 123-127.

Koide, R.T., Li, M., 1990. On host regulation of the vesicular-arbuscular mycorrhizal symbiosis. New Phytologist 114, 59-64.

Larsen, J., Olsson, P.A., Jakobsen, I., 1998. The use of fatty acids signatures to study mycelial interactions between the arbuscular mycorrhizal fungus Glomus intraradices and the saprotrophic fungus Fusarium culmorum in root-free soil. Mycological Research 102, 1491-1496.

Li, H., Smith, S.E., Holloway, R.E., Zhu, Y., Smith, F.A., 2006 Arbuscular mycorrhizal fungi contribute to phosphorus uptake by wheat grown in a phosphorus-fixing soil even in the absence of positive growth responses. New Phytologist 172, 536-543.

Liu, A., Hamel, C., Hamilton, R.I., Smith, D.L., 2000. Mycorrhizae formation and nutrient uptake of new corn (Zea mays L.) hybrids with extreme canopy and leaf architecture as influenced by soil $\mathrm{N}$ and $\mathrm{P}$ levels. Plant and Soil 221, 157-166.

Liu, A., Hamel, C., Begna, S.H., Ma, B.L., Smith, D.L., 2003. Soil phosphorus depletion capacity of arbuscular mycorrhizae formed by maize hybrids. Canadian Journal of Soil Science 83, 337-342.

Miller, M.H., 2000. Arbuscular mycorrhizae and the phosphorus nutrition of maize: a review of Guelph studies. Canadian Journal of Plant Science 80, 47-52.

Madan, R., Parkhurst, C., Hawke, B., Smith, S., 2002. Use of fatty acids for identification of AM fungi and estimation of the biomass of AM spores in soil. Soil Biology \& Biochemistry 34, 125-128.

Olsen, S.R., Sommers, L.E., 1982. Phosphorus. In: Page, A.L., Miller, R.H., Keeney, D.R. (Eds.), Methods of Soil Analysis, second ed. Agronomy Series No 9, Part 2. Soil Science Society of America, Inc., Madison, WI, pp. 403-430.

Olsson, P.A., 1999. Minireview. Signature fatty acids provide tools for determination of the distribution and interactions of mycorrhizal fungi in soil. FEMS Microbiology Ecology 29, 303-310.

Olsson, P.A., Johansen, A., 2000. Lipid and fatty acid composition of hyphae and spores of arbuscular mycorrhizal fungi at different growth stages. Mycological Research 104, 429-434.

Olsson, P.A., Bååth, E., Jakobsen, I., 1997. Phosphorous effects on mycelium and storage structures of an arbuscular mycorrhizal fungus as studied in the soil and roots by fatty acids signatures. Applied and Environmental Microbiology 63, 3531-3538.

Pfeffer, P.E., Douds, D.D., Bécard, G., Shachar-Hill, Y., 1999. Carbon uptake and the metabolism and transport of lipids in and arbuscular mycorrhiza. Plant Physiology 120, 587-598.

Plenet, D., 1995. Fonctionnement des cultures de maïs sous contrainte azotée. Determination et application d'un indice de nutrition. Dr. These Académie de Nancy-Metz, Institut National Polytechnique de Lorraine. 
Ritchie, S.W., Hanaway, J.J., Benson, G.O., 1997. How a corn plants develops. Spec. Publ. 48. Iowa State University Cooperative Extension Service, Ames, IA.

SAS Institute Inc, 1999. SAS/STATs User's Guide, Version 8. SAS Institute Inc., Cary, NC.

Schutter, M.E., Dick, R.P., 2000. Comparison of fatty acid methyl ester (FAME) methods for characterizing microbial communities. Soil Science Society of America Journal 64, 1659-1668.

Smith, S.E., Read, D.J., 1997. Mycorrhizal Symbiosis. Academic Press, London, 587pp. van Aarle, I.M., Olsson, P.A., 2003. Fungal lipid accumulation and development of mycelial structures by two arbuscular mycorrhizal fungi. Applied and Environmental Microbiology 69, 6762-6767.

White, D.C., Davis, W.M., Nickels, J.S., King, J.D., Bobbie, R.J., 1979. Determination of the sedimentary microbial biomass by extractable lipid phosphate. Oecologia 40, 51-62.

Zelles, L., 1999. Fatty acid patterns of phospholipids and lipopolysaccharides in the characterization of microbial communities in soil: a review. Biology and Fertility of Soils 29, 111-129. 